\section{Application of silviculture treatment to Support Rehabilitation on Logged Over Area (LOA) of Tropical Rainforest, Central Kalimantan, Indonesia}

\section{Widiyatno $^{\text {a*, M.Na'iem }}{ }^{\text {a }}$, M.Kanzaki ${ }^{\text {b, }}$ S.Purnomo ${ }^{c}$, and Jatmoko ${ }^{c}$}

${ }^{a}$ Faculty of Forestry, Universitas Gadjah Mada, Jl Agro No 1, Yogyakarta, 55281, Indonesia

${ }^{b}$ Graduate School of Agriculture, Kyoto University, Japan

${ }^{c}$ PT Sari Bumi Kusuma,Seruan-Central Kalimantan,Indonesia

Received:March 31,2013/Accepted:September 25, 2013

\begin{abstract}
The tropical rainforest cover of Indonesia is the second largest in the word and represents $48 \%$ of South-East Asia's or $24 \%$ of the world's tropical forest cover. One of the main tree family in Indonesian's rainforest is dipterocarpaceae. This family is also the most important timber family. Indonesia's tropical rainforest has been deforested rapidly and the remaining forest is largely degraded. The enrichment of the degraded forest using native dipterocarp species is required.

A plantation trial was established with two spacing types, two fertilizer dosages and five Shorea spp tree types as treatment. The highest and lowest survival rate at 6.5 years old were $86.7 \%$ for Shorea johorensis and $55.5 \%$ for $S$. virescent, respectively. The result of statistical analysis using ANOVA at 6.5 years old showed significant effects of treatments; ( 1 ) interactive effect of spacing $\mathrm{x}$ dosage $(\mathrm{F}=18.49, \mathrm{p}<0.0056)$ on diameter growth, (2) interactive effect of spacing $x$ dosage $(\mathrm{F}=7.58, \mathrm{p}<0.033)$ on height growth and (3) species effect $(\mathrm{F}=3.19, \mathrm{p}<0.021)$ on height growth. While the other treatments were not significant at a significance level of 0.05 for either diameter or height growth. S. leprosula exhibited the highest diameter and
\end{abstract}

* Corresponding author:

Tel: +62-274-545639; fax: +62-274-545639..

E-mail address: widiyatno.yk@gmail.com or widiyatno@ugm.ac.id height growth with MADI of $2.2 \mathrm{~cm}$. year ${ }^{-1}$ and MAHI of $1.32 \mathrm{~m}$. year ${ }^{-1}$ at 6.5 years. Almost equivalent growth was recorded by S. Johorensis and S. parvifolia. Those species known as fast growing species with high survival rate were recommended as the species for rehabilitation.

Keywords:growth, spacing, fertilizer, Shorea spp.

Abbreviations:
\begin{tabular}{|lll|}
\hline ANOVA & $:$ & Analysis of Variance \\
D & $:$ & Diameter \\
H & $:$ & Height \\
LOA & $:$ & Logged over area \\
MADI & $:$ & Mean Annual Diameter Increment \\
MAHI & $:$ & Mean Annual Height Increment \\
TPTI & $:$ & Tebang Pilih Tanam Indonesia - selective \\
& & cutting system \\
TPTJ & $:$ & Tebang Pilih Tanam Jalur - selective cutting \\
& & and strip planting method \\
\hline
\end{tabular}

\section{Introduction}

Indonesia is categorized as a mega biodiversity country and is ranked first in the word for number of mammals, palms, swallowtail butterflies, and parrot species [1]. One of the ecosystem types with mega diversity is tropical rainforestwhich occupies about $6 \%$ of total Earth's land surface but supports more than half of the total species diversity both land plants and animals [2,3]. Tropical rainforestcover of Indonesia is the second largest in the world and represents $48 \%$ of South-East Asia's or $24 \%$ of world's tropical forest cover. One of the main tree families in Indonesian tropical rainforest is Dipterocarpaceae. This family is distributed from India to New Guinea [4]. In Indonesia, the diversity of dipterocarp species is highest in Sumatra and Borneo Island where the number of dipterocarp species are 106 (10\% endemicity) and 267 (58\% endemicity) [5].

Dipterocarp trees in the forest are harvested to produce wood products because the wood is categorised as "fancy wood". The timber of dipterocarp (round-wood logs) accounts for $25 \%$ of total global consumption of tropical hardwood [6]. In the primary tropical rainforest the wood volume was estimated to be $212 \mathrm{~m} 3 \mathrm{ha}^{-1}$ where dipterocarps account for $86.9 \%$ of total volume [7].

In Indonesia, the tropical rainforest is mainly managed by two silviculture systems, the selective cutting system (Tebang Pilih Tanam Indonesia/TPTI)and a system combining selective cutting and strip planting (Tebang Pilih Tanam Jalur/TPTJ) [8]. In these systems, the diameter limit of commercial trees allowed to be harvested is greater than $40 \mathrm{~cm}$ and the cutting cycle is 30 years [8].Enrichment planting is conducted for theTPTI system if the regeneration of the residual stand is low[8]. Moreover, 
enrichment planting of the TPTJ system will be undertaken with strip planting where the number of seedling planted inthe area is 100-20o seedling/ha [8].

It has been reported elsewhere that TPTI residual stands contained various species but that the growth of small trees (dipterocarps) was delayed due to their reduced access to light[9]. Other reports have indicated thatTPTI operations damaged more than $50 \%$ of the trees, affecting the structure and composition of the logged over area (LOA) [10, 11, 12]. Moreover the increasing intensity of harvesting creates a large canopy opening and allows vine invasion [9]. The tree density of commercial trees in the LOA both in TPTI and TPTJ is low when compared to the non-commercial species in the forest, especially when harvesting intensity has been high [13].Today, a large area of Indonesia's tropical rainforest has become LOA. The rate of forest degradation in Indonesia has declined from 1,914,00o hayear ${ }^{-1}$ (1990200o), but is still at a very high rate 498 ,ooo hayear-1 (20002010) [14].

Deforestation and degradation of the tropical rainforest is also caused by land conversion to forest plantations, both legal and illegal logging, and other land uses such as palm oil plantations, mining, etc. The results of deforestation and degradation are an increase in the loss of biodiversity at both species and genetic levels. Deforestation and degradation will also result in the loss of a large carbon sink, forest function in hydrology, and non timber forest products.

In natural tropical rainforest, the mean annual diameter increment (MADI) of trees is as low as $0.22 \mathrm{~cm}_{\text {years }}{ }^{-1}$ and MADI of dipterocarps is $0.34-0.40 \mathrm{~cm}^{-1}$ years $^{-1}$ [13]. In one example, in the 2-4 years after harvesting, the MADI of the entire stand decreased to $0.18 \mathrm{~cm}$ year ${ }^{-1}$, and MADI of dipterocarps also decreased to $0.29 \mathrm{~cm}$ years $^{-1}$ [9]. The data indicated that the timber stock increment in the LOA is not sufficient to achieve sustainability with a 30 year rotation if it is not manipulated to increase the productivity and regeneration.

One of the techniques to increase commercial tree stock and productivity of LOA in tropical rainforest is enrichment planting using indigenous and valuable species, such as dipterocarps. Enrichment planting in tropical rainforest will have two main advantages: improving the sustainability of timber production and conserving the dipterocarp species. Research on enrichment planting in the tropical rainforest has been instigated to improve over-logged forests $[13,15$, 16]. Some species of dipterocarps identified as being useful for rehabilitation of the LOA were Shorea leprosula, $S$. parvivolia, S. johorensis and S. platycladosfor whichMADI was 1.16-1.3 cm. years ${ }^{-1}[13,17,18]$. However, very little information regarding silviculture treatment to rehabilitate LOA in tropical rainforest has been produced.

In this paper we focus on developing silviculture techniques to improve productivity and survival rates of Shorea species. The aim of the study is to test spacing, fertilizer dosage and the best species to support large scale dipterocarps plantations and rehabilitate LOA tropical rainforest.

\section{Methods}

\subsection{Experiment site}

The research was conducted in Sari Bumi Kusuma (SBK)

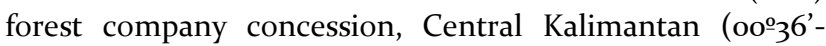
${ }^{\circ} 1^{\circ} 10^{\prime} \mathrm{S}$ and $\left.111^{\circ} 39^{\prime}-112^{\circ} 25^{\prime} \mathrm{E}\right)$. The silviculture system which was used to manage forests in the concession was TPTI and TPTJ, where the diameter limit allowed to be harvested was greater than $40 \mathrm{~cm} \mathrm{[5].} \mathrm{The} \mathrm{climate} \mathrm{type} \mathrm{is} \mathrm{type} \mathrm{A} \mathrm{(on} \mathrm{the}$ Schmit and Ferguson climate classification) where mean annual rainfall was 3,730 mmyear $^{-1}$ and the number of rainy days varied from 95 to 112 days.

\subsection{Seed collection}

Flowering and fruiting of dipterocarps is irregular with interval of 3-5 years and the seed is categorized as recalcitrant seed with less than one month viability after collection. The seeds of five dipterocarp species, $S$. leprosula, S.platyclados, S.parvifolia, S.virescens and S.johorensis, were collected during a mass flowering event from January to February 2005 in the whole of the concession area. As fallen fruit is eaten by animals, the fresh fruit was collected every day from the same collection sites. The fruit was sent to a nursery of SBK to be germinated and cultivated for 8 to 12 months in the nursery.

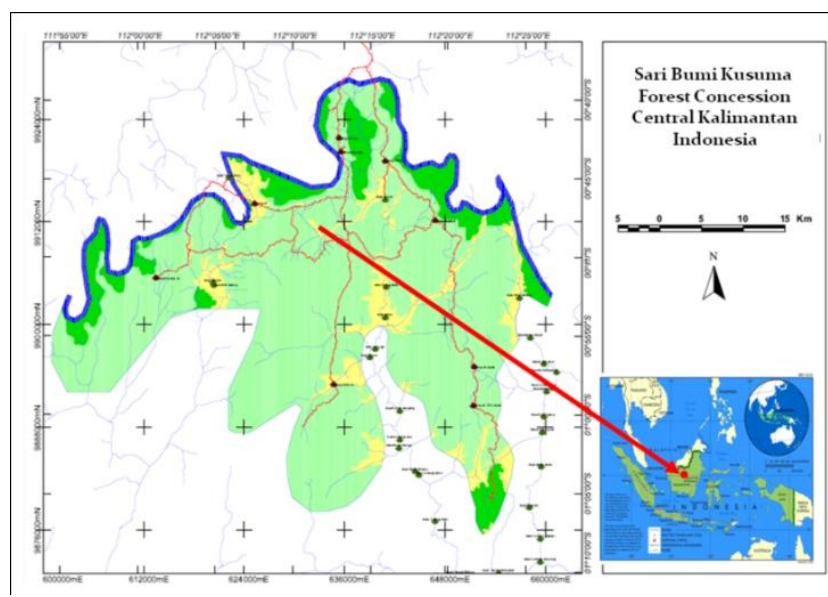

Figure 1 Location of the research site, Sari Bumi Kusuma forest company concession, Central Kalimantan, Indonesia

\subsection{Site preparationand planting}

An experiment was carried out in a 5.7 ha artificial gap formed in an LOA tropical rainforest. The gap was created from January to March 2006. Site preparation was done via clear cutting to ensure all of the treatments would be exposed to the same light and microclimate conditions. Clear cutting was also effective to control competing vegetation. Planting holes were approximately $40 \times 40 \times 30$ 
$\mathrm{cm}$. Site preparation and planting time was from February to April 2006.

\subsection{Experimental design}

Experimental plots were set in split-split plot arrangement with 4 replications. The main plot factor was two levels of tree spacing i.e. $6 \times 2 \mathrm{~m}$ and $6 \times 4 \mathrm{~m}$. The sub plot factor was two levels of dosage of NPK fertilizer applied to the planting holes, o and $100 \mathrm{~g}$ per tree. The sub-sub plot factor was 5 species of Genus Shorea, i.e. Shorea leprosula, S.platyclados, S.parvifolia, S.virescens and S.johorensis. Each sub-sub plot contained 30 trees (3x10 trees). The growth was monitored for the inner 8 trees excluding 22 border trees every 6 to 12months. Total tree height $(\mathrm{H})$ and stem diameter at breast height (D) was measured. The data was analyzed by Analysis of Variance (ANOVA) using the software SAS 9.o.

\section{Result and Discussion}

\subsection{Survival Rate}

The mortality rate of the dipterocarpswas high in the first year and slowed down until the third year. Between the third andsixth year, the mortality rate rose again. At 6.5 years after planting, the survival rates of S.johorensis, S.leprosula, S.parfivolia, S.platyclados and S.virescent were $86.7 \%, 84.4 \%, 72.9 \%, 65 \%$ and $55.5 \%$, respectively (Fig 2.)

Survival rates ofS.leprosulaover 2 years in South Kalimantan and 3 years in East Kalimatan were reported to be $60 \%$ and $74 \%$ respectively $[19,20]$. The survival rate of S.johorensis and S.parvifoliai at 2 years old in a species trial at Kintap, South Kalimantan, were $51 \%$ and $48 \%$ respectively [21].Compared to these reports, our experiment showed higher survival rates.

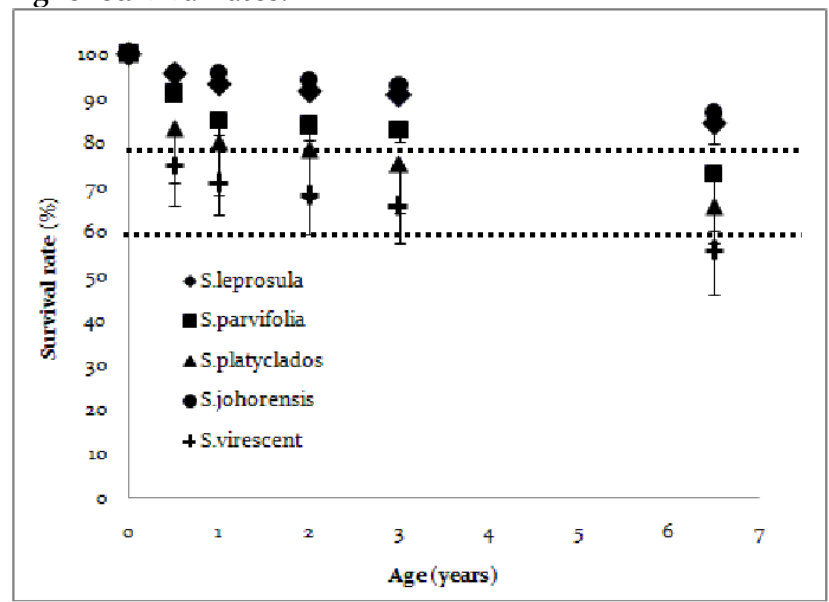

Figure 2 Survival rate of dipterocarps up to 6.5 years after plantation

The results indicated that the performance of the five species varied widely dependent on the ecological traits of the species [22]. In general dipterocarps need $30-50 \%$ of shading for the first one and a half years. After this, tolerance to light or demand for light subsequently increases $[23,24,25]$. Among dipterocarps, S.johorensis and
S.leprosula were more resistant to direct sunlight than the other dipterocaps [26] and normally showed high survival in open planting where trees suffered high heat stress in the early plantation establishment [26].

\subsection{Growth of Diameter and Height of Trees}

The results of statistical analysis using ANOVA for the height $(\mathrm{H})$ and diameter (D) of 6.5 years old trees showed a significant interaction effect between spacingand dosage $(\mathrm{F}=18.49, \mathrm{p}<0.0056)$ for $\mathrm{D}$. The interaction effects on $\mathrm{H}$ of spacing $x$ dosage $(\mathrm{F}=7.58, \mathrm{p}<0.033)$ and the effect of species treatment $(\mathrm{F}=3.19, \mathrm{p}<0.021)$ were also significant. While the other treatments were not significant at a significance level $t \alpha=0.05$ for either height or diameter variables (Table 1 ).

Table 1 Analysis of variance on silviculture treatments (spacing, dosage and dipterocaps species)

\begin{tabular}{|c|c|c|c|c|c|}
\hline \multirow[t]{2}{*}{ Source } & \multirow[t]{2}{*}{ DF } & \multicolumn{2}{|c|}{ Mean Square } & \multicolumn{2}{|l|}{$\operatorname{Pr}>F$} \\
\hline & & Diameter & High & Diameter & High \\
\hline Blok & 3 & 2.16 & $3 \cdot 30$ & & \\
\hline Spacing & 1 & $24 \cdot 35$ & 2.82 & $0.411 \mathrm{~ns}$ & $0.103 n s$ \\
\hline Error a & 3 & 26.93 & 0.52 & & \\
\hline dosage & 1 & 0.27 & 0.036 & o.699 ns & $0.766 n s$ \\
\hline $\begin{array}{l}\text { Interaction } \\
\text { between } \\
\text { dosage and } \\
\text { spacing }\end{array}$ & 1 & 30.51 & 2.78 & $0.00561^{* *}$ & $0.0331^{*}$ \\
\hline Error b & 6 & 1.65 & 0.37 & & \\
\hline Species & 4 & 1.09 & $4 \cdot 94$ & $0.862 \mathrm{~ns}$ & $0.021^{*}$ \\
\hline $\begin{array}{l}\text { Interaction } \\
\text { between } \\
\text { Species and } \\
\text { spacing }\end{array}$ & 4 & 6.82 & 1.67 & o.109ns & $0.376 \mathrm{~ns}$ \\
\hline $\begin{array}{l}\text { Interaction } \\
\text { between } \\
\text { Species and } \\
\text { dosage }\end{array}$ & 4 & 0.89 & 0.98 & o.901ns & $0.641 \mathrm{~ns}$ \\
\hline $\begin{array}{l}\text { Interaction } \\
\text { between } \\
\text { Species, } \\
\text { spacing and } \\
\text { dosage }\end{array}$ & 4 & 4.66 & 1.77 & $0.260 \mathrm{~ns}$ & $0.347 \mathrm{~ns}$ \\
\hline Error c & 48 & 3.41 & 1.55 & & \\
\hline Total & 79 & & & & \\
\hline
\end{tabular}

Note: $n s=$ non significant ${ }^{*}=$ significant at 0.05 level of probability ; ${ }^{* *}=$ significant at 0.01 level of probability

\subsection{Species effect}

Species effects were significant only in height growth (Table 1 and Figure 4). S.leprosula performed the best both in

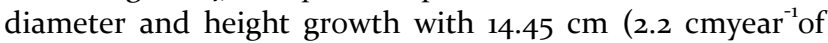
mean annual diameter increment: MADI) and $8.63 \mathrm{~m} \mathrm{(1.32}$ $\mathrm{m}$ year $^{-1}$ of mean annual height increment: MAHI), respectively, at 6.5 yrs old. 
$\mathrm{D}$ and $\mathrm{H}$ of S.parvifolia at 6.5 years old were $14.07 \mathrm{~cm}$ $(\mathrm{MADI}=2.16 \mathrm{~cm}$ year-1 of $)$ and $7.97 \mathrm{~m}\left(\mathrm{MAHI}=1.22 \mathrm{~m}\right.$ year $^{-}$ $\left.{ }^{1}\right)$, respectively. S.parvifolia can be found on clay soil on hills below $800 \mathrm{~m}$ above sea level and is considered a fast grower [4].

$\mathrm{D}$ and $\mathrm{H}$ of $S$.johorensis at 6.5 years old were $13.79 \mathrm{~cm}$ (2.12 cm.year ${ }^{-1}$ of MADI) and 7.65 m (1.17 m year $^{-1}$ of MADI), respectively. It has natural distribution range in Peninsular Malaysia, Sumatra and Borneo. It grows best on sites of well-drained alluvium and undulating soil up to $600 \mathrm{~m}$ above sea level [4].
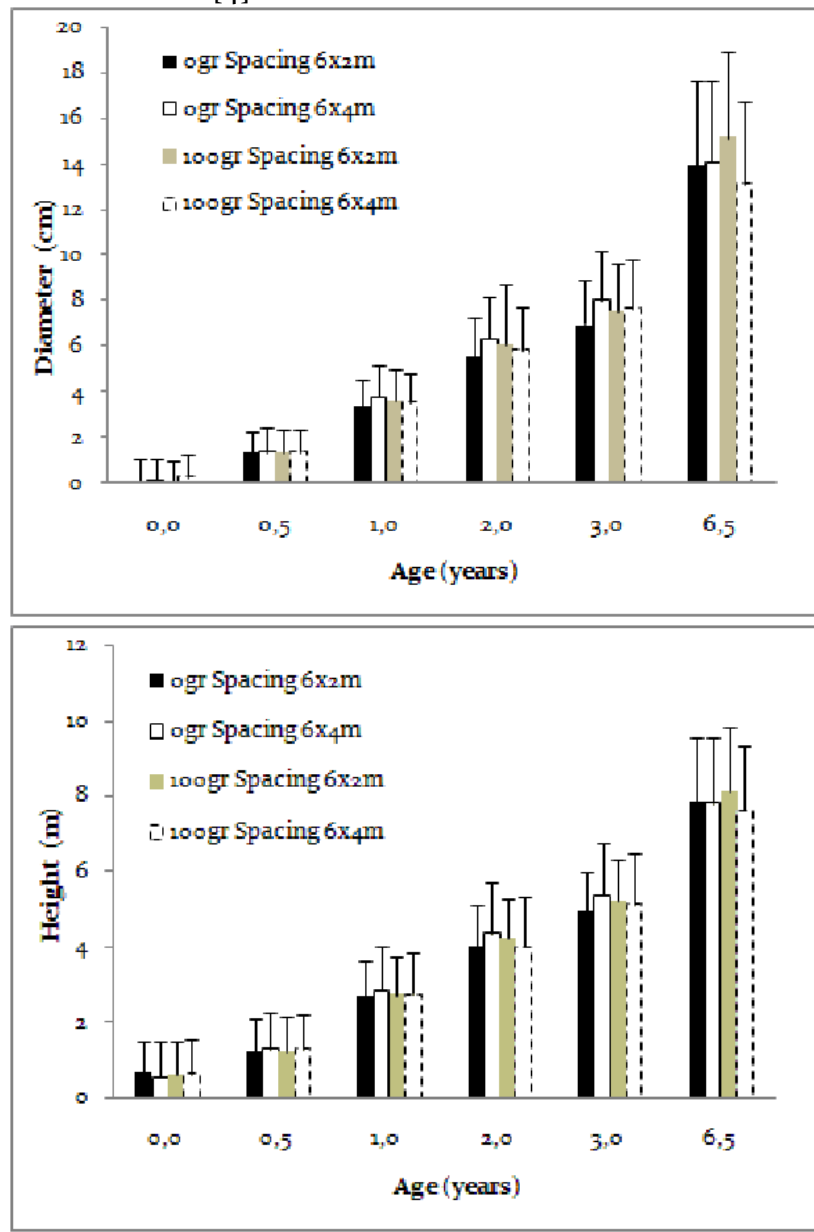

Figure 3 The spacing and fertilizer dosage of NPK did not affect growth significantly at diameter and height variables.

D and H of S.platycladosat 6.5 years old were $14.35 \mathrm{~cm}$ $\left(2.20 \mathrm{~cm}\right.$. year $^{-1}$ of MADI $)$ and $7.93 \mathrm{~m}\left(1.22 \mathrm{~m}\right.$. year $^{-1}$ of MAHI), respectively. This species has widely spread in lower mountain forest usually between 700 to $1,300 \mathrm{~m}$ above sea level, in peninsular Malaysia, occasionally down to $200 \mathrm{~m}$ in valley bottoms near mountains. By contrast, in Borneo the species grows down to $70 \mathrm{~m}$ above sea level.

The growth of S.virescenst on height and diameter were $2.12 \mathrm{~cm}_{\text {.year }}{ }^{-1}$ and $1.07 \mathrm{~m}$ year ${ }^{-1}$ respectively (Fig 4). S.virescenst has a narrow distribution range and can be found on flat and undulating land with fertile clay loams and hills $800 \mathrm{~m}$ above sea level.
The growth performance of the three species, S.johoriensis and S.leprosula, and S. parvifolia, were better than the growth rate reported by other sources. Adjers et al. [13] reported that at 2 years after planting of S.johoriensis and S.leprosula,S. parvifolia, heights were less than $2.5 \mathrm{~m}$. Appanah and Weinland [25] reported that the growth of $S$. leprosura and S. parvifolia at Kepong, Peninsula Malaysia, was $0.75-1.2 \mathrm{~cm}$ year ${ }^{-1}$ and $1.2 \mathrm{~cm}$ year $^{-1}$ in MADI for first 30 years, respectively.

S.johorensis was reported to exhibit slow growth in the line planting system ( $3 \mathrm{~m}$ planting strip width) where the survival rate and MADI at 2 years were less than $70 \%$ and $0.6 \mathrm{~cm}$ year $^{-1}$, possibly because the species was sensitive to excess light and/or high temperature [13].This result was contradictory to our result, in which S.johorensis in the open area had $93 \%$ survival and 2.51 cmyear $^{-1}$ MADI at 6.5 years old. The quite high survival and growth in the present study may be due to better land preparation techniques, whereby in this study horizon-A was added to across the whole plantation and the upper soil layer in the research location remained continuously moist.

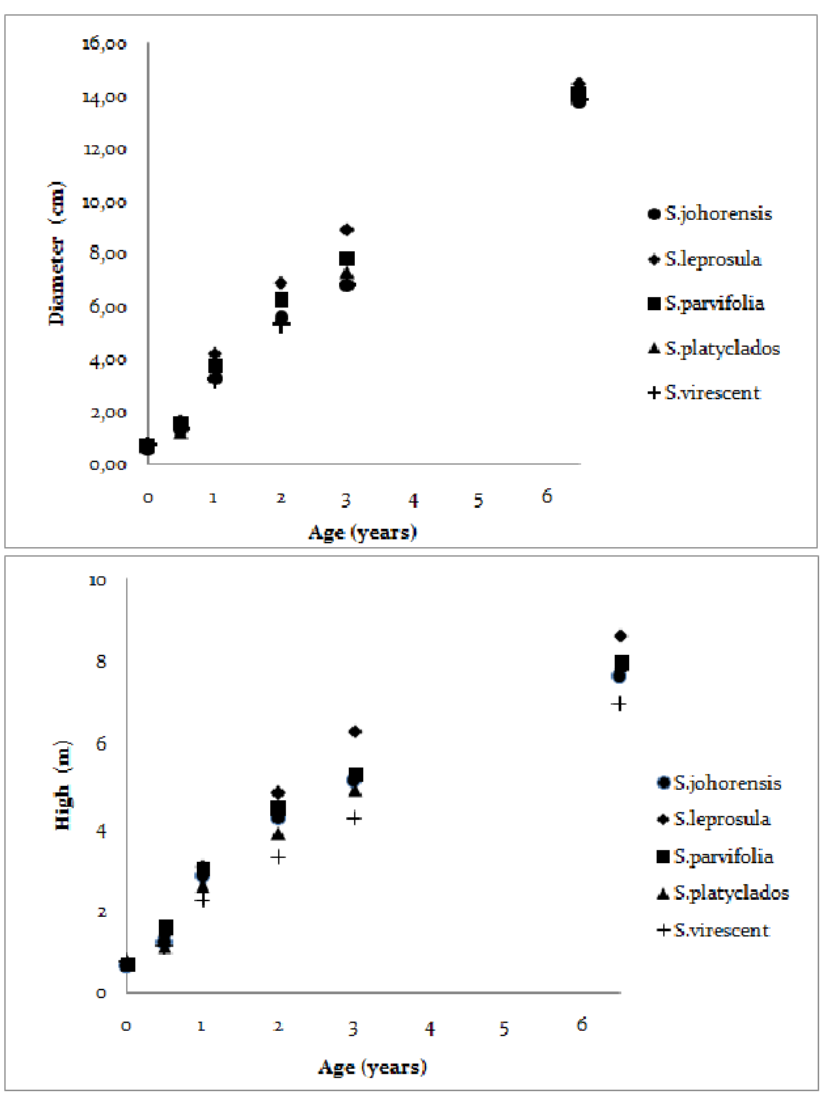

Figure 4 (a) The D growth of 5 dipterocarps species; (b) The $\mathrm{H}$ growth of 5 dipterocarps species 


\subsection{Perspectives online planting for enrichment of LOA}

Enrichment of LOA by line planting started in Indonesia from 1997 as a standard silvicultural method as TPTJ. In this method, planting strips of $3 \mathrm{~m}$ width are made at $20 \mathrm{~m}$ intervals in LOA and Shorea trees are planted with 2.5 or 5 $\mathrm{m}$ spacing. This method causes very limited disturbance to the existing LOA ecosystem $[26,27]$. The planting strip openings occupy less than $15 \%$ of land area and trees especially dipterocarp and protected trees species i.e. Eusideroxylon zwageri, Garcinia sp., Durio dulcis; Sindora wallichii, Tengkawang, Dyera sp. etc. $[28,29]$ are not cut even if the trees are located in planting strips. On the other hand, TPTJ causes soil compaction and a decrease in infiltration capacity in the early establishment of plantation. Moreover, infiltration in the TPTJ system after 10 years was similar to that ofvirgin forest, indicating that TPTJ would increase productivity of timber without negative impact on infiltration [30]. The TPTJ system also had a positive impact on the prevalence of 17 carnivore species, including three species listed as Endangered (Flat-headed Cat Prionailurus planiceps, Bay Cat Pardofelis badia and Otter Civet Cynogale bennettii) and six as Vulnerable (Banded Civet Hemigalus derbyanus, Hose's Civet Diplogale hosei, Binturong Arctictis binturong, Sunda Clouded Leopard Neofelis diardi, Marbled Cat Pardofelis marmorata and Sun Bear Helarctos malayanus) which appear on The IUCN Red List of Threatened Species[31].

For species growth, increasing available light to the forest floor by creation of planting strips will increase sun flecks in the forest floor where the planted Shorea trees grow. Diffuse light intensity is very low [32] and contribution to undergrowth trees is low. Sun flecks consist of high intensity in the red light spectrum composed of uniform spectral energy between $400-800 \mathrm{~nm}$, while open sunlight has a peak at $450 \mathrm{~nm}$ with gradual decline towards the red light spectral region [32]. Sun flecks yield sufficient energy to promote growth of plants in understory layers in the forest [33]. Gap creation for line planting in LOA can increase the occurrence of sun flecks and is expected to increase the survival rate and growth of planted dipterocarps.

Based on our survival and growth performance test, $S$. johorensis, S. leprosula and S. parvifolia exhibited the best performance in open areas. These species could be recommended as the main species for rehabilitation of tropical rainforest. These species are considered to be among the more light-demanding species of the genus Shorea, exhibited high tolerance to open conditions and have potential to be planted in degraded tropical rainforest [34].

Apanah and Weinland [25] suggested that to obtain optimum growth, especially in line planting, the over-story in the planting strip must be removed [25]. This suggestion was in line with our result where $S$. johoriensis, $S$. leprosula, and $S$. parvifoliaare shown to grow well in open sites and benefit from the removal of over-story trees. Removal of over-story trees before planting is likely to have other advantages, including: (1) decreasing damage of planted trees and (2) improving quality of opening area to support of seedling [21].

Selection of species is also important to get success in large scale dipterocarp plantations because each species of dipterocarp has different growth performance and microclimate requirement [5]. Choosing species of dipterocaps especially of light-demanding dipterocarp species with TPTJ is very important to improve productivity of LOA, forest ecological services provision and forest sustaninable management (FSC). Sist el al[35] reported that because the MADI of the remaining dipterocarp stands of LOA was less than $0.4 \mathrm{~cm}_{\text {year }}{ }^{-1}[13]$., in order to maintainsustainability of forest management in Indonesia, the rotation of cutting cycles was varied from 40-90 years [35]. This option is not good from theeconomic aspect so the TPTJ system with appropriate silviculture techniques may be used toreduce the cutting cycle (to around 25 years) [8]., preventing dipterocarps from extiction and also increasing forest productivity in the future.

\section{Conclusion}

In order to have successful large scale plantations of dipterocarps in the secondary tropical rainforest it is very important to choose species that have good growth and also high survival rates. In Indonesia, S. johorensis, S. leprosula, and S. Parfivolia can be chosen as indigeneous species to rehabilitate theLOA of tropical rainforest. The diameterand height growth were more than $2 \mathrm{~cm}$.year ${ }^{-1}$ and 1 m.year ${ }^{1}$ respectively and the survival rate was more than $70 \%$ for selected dipterocarp species. On the other hand, with regards to the silviculture technique, a combination of 100 gr of NPK fertilizer and spacing of $6 \times 2 \mathrm{~m}$, was shown to be the best treatment to improve the growth of selected dipterocarps.

\section{Acknowledgements}

This study was made possible by PT Sari Bumi Kusuma and the Ministry of Forestry of Indonesia who funded this research. We would also like thank the Dean of the Faculty of Forestry for allowing us to conduct this research. In particular, thanks are due to the R\&D staff of PT SBK for their help in carrying out this experiment especially for frequent maintenance and measurement during this research.

\section{References}

[1] World Bank. Indonesia: Environment and Tarural Resource management in a Time of Transition. 2001.

[2] Primack RB, Corlett RT. Tropical Rainforests: An Ecological and Biogeographical Comparison. Blackwell Science, Oxford; 2005.

[3] Whitmore TC. An Introduction to Tropical Rainforests, and ed. Oxford University Press, Oxford; 1998 
[4] Newman MF, Burges PF, Whitmore TC.Manual of Dipterocarps for Forester: Borneo Island Light Hardwoods, Anisptera, Parashorea, Shorea (Red, White and Yellow Meranti). Jakarta: Royal Botanic Garden Edinburgh\&Cifor;1996.

[5] Ashton PS. Dipterocarpaceae. Flora Malesiana, Series I. Netherlands: Martinus Nijhoff Publishers; 1982.

[6] ITTO. Annual review and assessment of the world's timber situation. International Tropical Timber Organisation. Yokohama;2008

[7] Bischoff W, Newbery DM, Lingenfelder M, Schnaeckel R, Petol GH, Madani L, Ridsdale. CE. Secondary succession and dipterocarp recruitment in Bornean rainforest after logging. For Ecol Manage; 2005; 218: 174-192

[8] Ministry of Forestry (2009) Decree no: 11/Menhut-II/2009: Silvicultural System in The Natural Forest productions. Ministry od Forestry. Jakarta Indonesia

[9] Sist P, Nguyen-The N. Logging damage and the subsequent dynamics of a dipterocarp forest in East Kalimantan (19901996). Forest Ecology and Management; 2002; 165: 85-103.

[10] Sist, P, Fimbel R, Sheil D, Nasi R, Chevallier MH. Towards sustainable management of mixed dipterocarp forests of Southeast Asia: moving beyond minimum diameter cutting limits. Environmental Conservation 2003; 30:364-374.

[11] Kartawinata k, Riswan S, Ginting AN, Puspitojati t. 2001. An Overview of Post Extraction Secondary Forests In Indonesia. Journal of Tropical Forest Science 2001; 13(4): 621-638.

[12] Pinard MA, Putz FE. Retaining forest biomass by reducing logging damage. Biotropica 1996; 28: 278-295.

[13] Adjers G, Hadengganan S, Kuusipalo J, Nuryanto K, Vesab L Enrichment planting of dipterocarps in logged-over secondary forests: effect of width, direction and maintenance method of planting line on selected Shorea species. Forest Ecology Management; 1995, 73:259-270

[14] Food and Agriculture Organisation (FAO), Global Forest Resources Assessment Rome:FAO. 2010. Available from: http://www.fao.org/docrep/o13/i1757e/i1757e.pdf.

[15] Sovu TigabuM, Savadogo P, Ode'n PC, Xayvongsa L. Enrichment planting in a logged-over tropical mixed deciduous forest of Laos. J For Res; 2010, 21:273-280

[16] Millet J, Tran N, Vien Ngoc N, Tran Thi T, Prat D. Enrichment planting of native species for biodiversity conservation in a logged tree plantation in Vietnam; New Forests. 2013; 44:369-383.

[17] Shono K, Davies SJ, Chua YK. Performance Of 45 Native Tree Species On Degraded Lands In Singapore. Journal of Tropical Forest Science; 2007, 19(1): 25-34

[18] Hassan A, Wahab R, Alias MA, Salim RM. Growth Performance of 9-Years-old selected 5 Indigenous Wood Species Planted on Degraded Forest Land. International Journal of Agriculture Research; 2007, 2(3):302-306

[19] Otsamo R, Adjers G, Hadi TS, Kuusipalo J, Otsamo A. A. Early performance of 12 shade tolerant tree species interplanted with Paraserianthes falcataria on Imperata cylindrica grassland. Journal of Tropical Forest Science 1996; 8(3):381-394.

[20] Efendi R, Priadjati A, Omon M, Rayan, Tolkam GW, Nasri E. Rehabilitation of Wanariset Secondary Forest (East Kalimantan) through Dipterocarp Species Line Planting. In: Hillegers PJM, De long $\mathrm{HH}$, editors. The Balance between Biodiversity Conservation and Sustainable Use of Tropical Rainforests, The Netherland: The Tropenbos Foundation; 2001, p.31-44

[21] Adjers G, Nuryanto K., Kuusipalo J. Rehabilitation of degraded dipterocarp forest: results from South Kalimantan, Indonesia.
In: Appanah S, Khoo KC, editors. Proceedings of the Fifth Round-table Conference on Dipterocarps, Kuala Lumpur: Forest Research Institute Malaysia;1996, p.316-334.

[22] Pedraza RA., Williams-Linera G. Evaluation of native tree species for the rehabilitation of deforested areas in a Mexican cloud forest. Kluwer Academic Publisher: New Forests 2003; 26: 83-99.

[23] Aminah H, Basok BIZ, Rosdi K, Rozihawati Z, Ahmad Fauzi MS, Hamzah M. Growth performance of some dipterocarps and non-dipterocarps planted from rooted cuttings. In:Proceedings of the Eight Round-table Conference on Dipterocarps. Ho Chi Minh City. Vietnam. 2005.

[24] Sasaki S, Mori T. Growth Response of Dipterocarp Seedling to Light. Malaysian Forester; 1981; 44:319-346.

[25] Appanah S, Weinland G. Planting Quality Timber Trees In Peninsular Malaysia. Kepong: Forest Research Institute Malaysia; 1993.

[26] Soekotjo. Intensive silviculture to improve productive capacity of forests: Large scale enrichment planting of dipterocarps. In: proceeding of XIII World Forestry Congress. Buenos Aires, Argentina; 2009, p.1-10.

[27] Na'iem M, Faridah E. Model of Intensive Enrichment Planting (TPTII).In: Rimbawanto A. Silviculture Systems of Indonesia's Dipterocarps Forest Management A Lesson Learned. Faculty of Forestry.Yogyakarta: University of Gadjah Mada, ITTO:2006, p. 25-36.

[28] Minister of Agriculture. Decree No. 54/KPTS/Um/1972: The Protected Trees Species in The Forest Area. Minister of Agriculture. Jakarta-Indonesia. 1972.

[29] Ministry of Forestry. Decree: No. 261/Kpts-IV/1990: The Protected Trees Species in The Forest Area. Ministry of Forestry, Jakarta-Indonesia. 1990

[30] Suryatmojo H, Widiyatno, Purnomo S. The Impcat of Line Planting on Infiltration. In: Rimbawanto A, Febrianto F, Komar TE, editors. Proceeding of International Seminar Research Plantation Forest Management: Challenges and Opportunities. Center for Plantation Research and Development. 2009, p.229-236

[31] Samejima H, Semiadi G. First record of Hose's Civet Diplogale hosei from Indonesia, and records of other carnivores in the Schwaner Mountains, Central Kalimantan, Indonesia. Small Carnivore Conservation 2012; 46:1-7

[32] Priadjati A, Tolkamp GW. Initial Growth of Shorea leprosula cutting under The Shade of Penorema canescens. In: Aminah H, Ani S, Sim HC, Krisnapillay B, Editors. Proceeding of The Seventh Round-Table Conference on Dipterocarps, Kuala Lumpur: Asia Pacific Association of Forestry Research Institution (APAFRI); 2003, p.188-201.

[33] Yasman. I. Dipterocarpaceae: Tree-Mychorrhizae-Seedling Connection. PhD. Thesis. Wegeningen Agriculture University. Netherland. 1995.

[34] Mun WK, HUat OK, Hung JK. Growth and Eco-Physiology of Shorea Species in Planted Forest. Majid NKM, Ahmad OH, ISLAM MDM, Sajap AS (editors). Rehabilitation of Tropical Rainforest Ecosystem. Kuala Lumpur: Universitas Putra Malaya, 2011, p.449-452.

[35] Sist P, Picard N, Gourlet-Fleury S. Sustainable Cutting Cycle and Yields in Lowland Mixed Dipterocarp Forest of Borneo. Annal of Forest Science 2003; 60:803-814. 